\title{
Correction to: exploratory mathematics talk in a second language: a sociolinguistic perspective
}

\author{
Sally-Ann Robertson ${ }^{1}$ (D) $\cdot$ Mellony Graven ${ }^{1}$ \\ Published online: 16 October 2019 \\ (C) The Author(s) 2019
}

\section{Correction to: Educational Studies in Mathematics (2019) 101(2):215-232 https://doi.org/10.1007/s10649-018-9840-5}

The article "Exploratory mathematics talk in a second language: a sociolinguistic perspective", written by Sally-Ann Robertson and Mellony Graven, was originally published Online First without Open Access. After publication in volume 101, issue 2, page 215-232 the author decided to opt for Open Choice and to make the article an Open Access publication. Therefore, the copyright of the article has been changed to (C) The Author(s) 2018 and the article is forthwith distributed under the terms of the Creative Commons Attribution 4.0 International License (http://creativecommons.org/licenses/by/4.0/), which permits use, duplication, adaptation, distribution and reproduction in any medium or format, as long as you give appropriate credit to the original author(s) and the source, provide a link to the Creative Commons license, and indicate if changes were made.

The original article has been corrected.

Open Access This article is distributed under the terms of the Creative Commons Attribution 4.0 International License (http://creativecommons.org/licenses/by/4.0/), which permits unrestricted use, distribution, and reproduction in any medium, provided you give appropriate credit to the original author(s) and the source, provide a link to the Creative Commons license, and indicate if changes were made.

Publisher's note Springer Nature remains neutral with regard to jurisdictional claims in published maps and institutional affiliations.

The online version of the original article can be found at https://oi.org/10.1007/s10649-018-9840-5

Sally-Ann Robertson

s.a.robertson@ru.ac.za

1 South African Numeracy Chair Project (SANCP), Education Department, Rhodes University, PO Box 94, Grahamstown 6140, South Africa 